\title{
Estudio experimental del Sistema de Albañilería Integral en la construcción de viviendas sismorresistentes
}

\author{
Experimental study of the Integral Masonry System \\ in the construction of earthquake resistant houses
}

\author{
B. Orta $^{(*)}$, R. Bustamante $(*)$, J. M. Adell(*)
}

Recepción/Received: 11-XI-10

Aceptación/Accepted: 14-II-11

\section{RESUMEN}

Este artículo presenta una aplicación del Sistema de Albañilería Integral (SAI) a la construcción de viviendas sismorresistentes y su estudio experimental. Para verificar su seguridad para su construcción en zonas sísmicas del tercer mundo se han ensayado dos prototipos, uno con adobe, y otro con ladrillo hueco. Se trata de una vivienda de $6 \times 6 \times 6 \mathrm{~m}^{3}$ y dos plantas que se construyen a escala $1 / 2$. Los ensayos se realizaron en el Laboratorio de Estructuras Antisísmicas del Departamento de Ingeniería de la Pontificia Católica Universidad del Perú (PUCP) de Lima en colaboración con la UPM (Universidad Politécnica de Madrid).

Este artículo muestra el proceso de diseño de los prototipos a ensayar, incluido el dimensionado de los refuerzos, las características de los ensayos y los resultados obtenidos. Estos resultados muestran que el SAI con adobe $\mathrm{o}$ ladrillo permanece estable sin grietas significativas ante un sismo severo, con una aceleración estimada de $1,8 \mathrm{~g}$.

Palabras clave: adobe, ladrillo, sistema de albañilería integral, diseño de estructuras, análisis sísmico.

\section{SUMMARY}

This paper presents the application of the Integral Masonry System (IMS) to the construction of earthquake resistant houses and its experimental study. To verify the security of this new type of building in seismic areas of the third world two prototypes have been tested, one with adobe and the other with hollow brick. In both cases it's a two-story $6 \times 6 \times 6 \mathrm{~m}^{3}$ house built to scale $1 / 2$. The tests are carried out at the Laboratory of Antiseismic Structures of the Department of Engineering, Pontifical Catholic University of Peru in Lima, in collaboration with the UPM (Technical University of Madrid).

This article shows the design process of the prototypes to test, including the sizing of the reinforcements, the characteristics of the tests and the results obtained. These results show that the IMS with adobe or brick remains stable with no significant cracks faced with a severe earthquake, with an estimated acceleration of $1.8 \mathrm{~g}$.

Keywords: adobe, brick, integral masonry system, structures design, seismic analysis.

(*) Universidad Politécnica de Madrid (UPM). 


\section{INTRODUCCIÓN}

En mayo de 2005, profesores de la Universidad Politécnica de Madrid presentaron en el Seminario Internacional SismoAdobe 2005 (1), organizado en Lima, en la Pontificia Universidad Católica del Perú, la ponencia "La vivienda de adobe sismorresistente con el Sistema de Albañilería Integral", un nuevo sistema constructivo ideado para países en desarrollo, basado en los materiales del lugar, aunque armados con una nueva técnica. El seísmo ocurrido en Pisco (Perú) en agosto de 2007, y los recientes sismos de Haití en enero de 2010 y de Chile en febrero de 2010 ponen de actualidad la necesidad de experimentar la propuesta presentada en su día, con el fin de poder implantar este sistema constructivo alternativo que posibilita la reconstrucción de las viviendas derruidas por los seísmos, con la seguridad necesaria ante cualquier otra catástrofe posible. Gracias a los proyectos de investigación concedidos por la Universidad Politécnica de Madrid en su programa de actividades con América Latina, se han ensayado dos prototipos, el primero en 2008 (proyecto AL08-P(i+D)-01) con el relleno de adobe (2) y el segundo en 2009 (proyecto AL09$\mathrm{P}(\mathrm{i}+\mathrm{D})-02)$ con el relleno en ladrillo hueco. Los resultados de estos ensayos se muestran a continuación.

\section{INTRODUCTION}

In May 2005, professors of the Universidad Politécnica of Madrid took part at the International Seminar SismoAdobe 2005 (1), organised in Lima, at the Pontifical Catholic University of Peru. They introduced the paper "Earthquake resistant adobe dwelling with the Integral Masonry System", a new constructive system devised for developing countries, based on the local materials although reinforced with a new technique. The earthquake which happened in Pisco (Peru) in August 2007, and the recent earthquakes in Haiti in January 2010 and Chile in February 2010 focus attention the necessity to experiment the proposal previously presented. With the aim of introducing this alternative constructive system which makes possible the rebuilding of the dwellings demolished by the earthquakes, with the necessary security when faced with any other possible disaster. Thanks to the research projects given by the Universidad Politécnica of Madrid in its program of activities with Latin America, two prototypes have been tested, the first one in 2008 (project AL08-P(i+D)-01) with adobe filler (2) and the second one in 2009 (project AL09-P(i+D)-02) with hollow brick filler. The results of these tests are shown next.

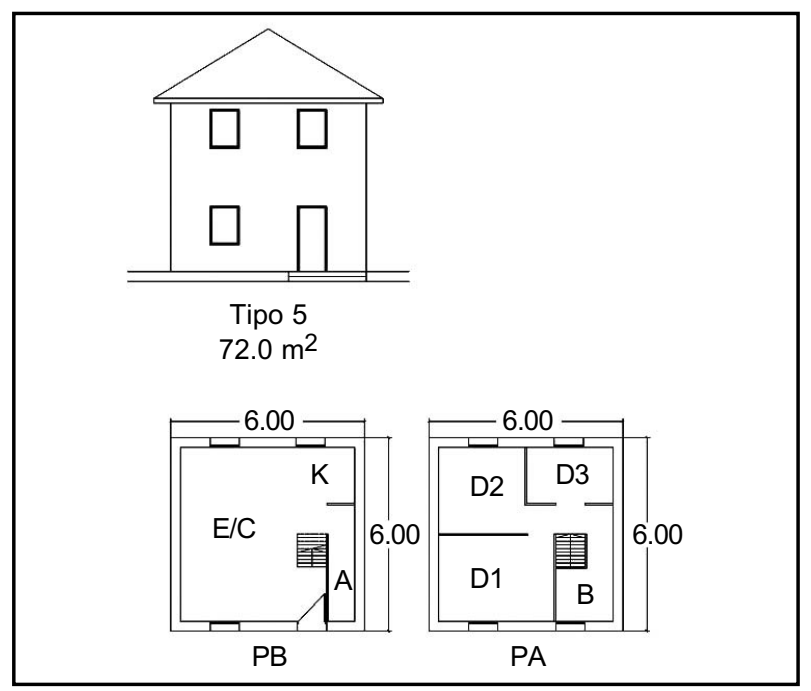

Figura 1. Vivienda a ensayar.

Figure 1. Dweling for testing.

\section{DESCRIPCIÓN}

El objetivo de este artículo es mostrar el estudio experimental que se está llevando a cabo para verificar el comportamiento sismorresistente del SAI en la construcción de viviendas, además de verificar los dos tipos de relleno planteados sometidos al mismo ensayo sísmico. Se ha escogido ensayar la vivienda Tipo 5 (Figura 1) de las 6

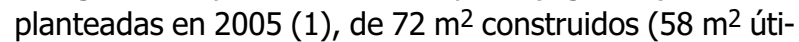
les), dos plantas de altura y 3 dormitorios, por tratarse de

\section{DESCRIPTION}

The objective of this article is to show the experimental study that's being carried out to verify the seismicresistant performance of the IMS in the construction of dwellings. As well as verifying the two types of proposed filler subjected to the same seismic test. Out of the 6 houses proposed in 2005 (1), Type 5 (Figure 1) has been chosen for testing, with $72 \mathrm{~m}^{2}$ built (58 $\mathrm{m}^{2}$ useable), two-story high and 3 bedrooms, because it's a cubic 
un volumen cúbico. Tiene $6 \mathrm{~m}$ de lado, perfectamente adaptable a las posibilidades de ensayo de la mesa sísmica del laboratorio (cuadrada de $4 \mathrm{~m}$ de lado), que permite ensayar el conjunto de la vivienda a escala $1 / 2$. Se comparan los dos prototipos y se analiza su respuesta ante el ensayo. Las características del prototipo son las siguientes.

\subsection{Características del refuerzo}

La tecnología de armado empleada consiste en armaduras prefabricadas en forma de cercha, con alambres longitudinales y transversales en zigzag, de acero B-500-S, ya soldados entre sí y con un recubrimiento galvanizado que evita su corrosión. La forma de la cercha es tal que optimiza su resistencia a flexión para diferentes tipos de carga (3) a la vez que facilita el proceso de prefabricación. Se utiliza el mismo sistema en muros y en forjados (Figura 2). Este sistema lo comercializa en Europa la empresa Allwall System para refuerzo de muros de ladrillo o bloque (4).

Independientemente del relleno empleado, las armaduras de refuerzo transmiten los esfuerzos entre sí por medio de uniones atornilladas o soldadas, por lo que no es necesario el empleo de mortero. El esquema de armado con cerchas prefabricadas de alambre galvanizado que se cruzan en las tres direcciones del espacio hace posible construir muros y forjados con el mismo sistema. De esta manera solo se necesita un posterior relleno para que el conjunto tenga la rigidez suficiente (Figura 3).

Para hacer el dimensionado se realiza un análisis sísmico según la normativa peruana NTE E.030 (5) considerando la mayor aceleración sísmica considerada en el documento, $0,4 \mathrm{~g}$. De esta manera el sistema se podría construir en cualquier zona del país. Debido a las características de la estructura, albañilería armada, la norma permite utilizar un coeficiente de reducción de la fuerza

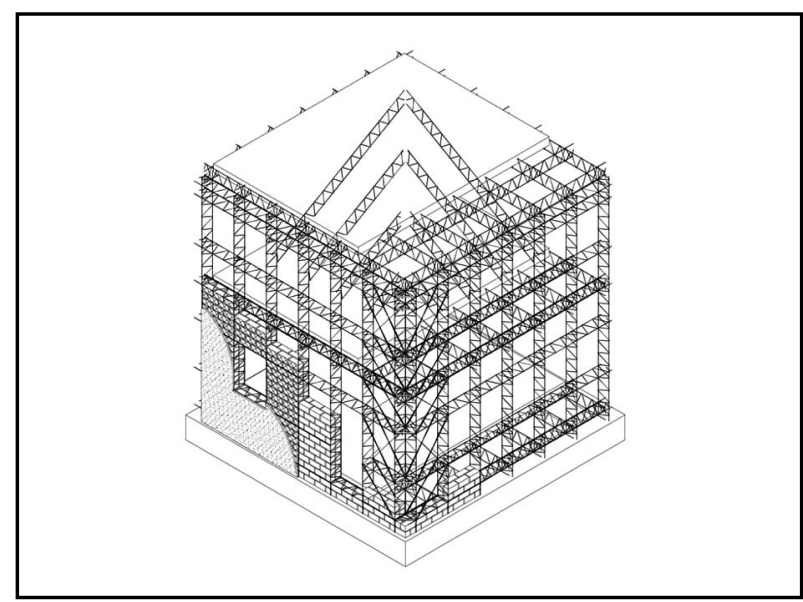

Figura 2. Vista en 3D del modelo a ensayar. Figure 2. 3D view of the model for testing. volume. It's $6 m$ wide. It's perfectly adaptable to the testing possibilities of the laboratory's earthquake shaking table (square, $4 \mathrm{~m}$ wide), which allows testing the house as a whole to scale 1/2. Both prototypes are compared and their response to the test is analysed. The characteristics of the prototype are the following ones.

\subsection{Characteristics of the reinforcement}

The reinforcement technology used consists of prefabricated bars in the form of a truss. Longitudinal and transverse in zigzag wires, of steel B-500-S, already welded to each other and with a galvanized coating which prevents their corrosion. The truss form is such that optimises its resistance to flexion for different types of load (3) and simultaneously facilitates the process of prefabrication. The same system is used for walls and floors (Figure 2). This system is marketed in Europe by the company All wall System for reinforcement of brick or block walls (4).

Regardless of the filler used the bars transfer the internal stresses to each other through screwed or welded assemblies, hence the necessity to use mortar. The reinforcement diagram with prefabricated trusses of galvanised wire which cross in the three spatial directions makes possible the construction of walls and floors with the same system. This way only subsequent filler is needed so that the set has enough rigidity (Figure 3).

To do the sizing a seismic analysis is carried out according to the Peruvian regulation NTE E.030 (5) taking into account the higher seismic acceleration considered in the document, $0.4 \mathrm{~g}$. This way the system could be built in any are in the country. Due to the characteristics of the structure, reinforced masonry, the regulation allows the use of a reduction of the seismic

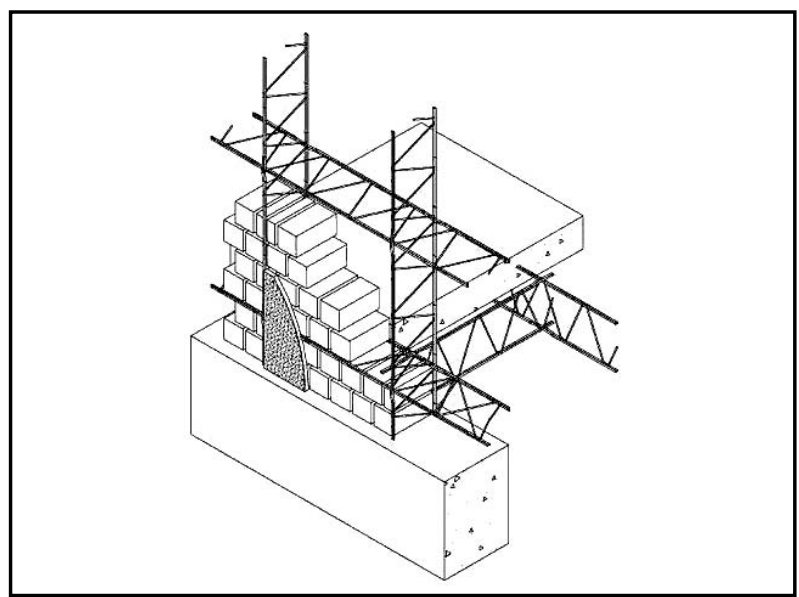

Figura 3. Esquema de armado con cerchas prefabricadas. Figure 3. Framework diagram with prefabricated trusses. 
sísmica, debido a que considera que los elementos de armado horizontal y vertical, permiten la disipación de la energía manteniendo la estabilidad de la estructura, este coeficiente es de 6 para esfuerzos admisibles y 3 para deformaciones. Debido a la zona sísmica (zona 3), a la categoría de edificación (vivienda) y a la regularidad estructural, la norma permite emplear cualquier tipo de sistema estructural. Por otra parte debido a la altura de la estructura y su regularidad, esta norma permite realizar un cálculo estático de fuerzas equivalentes y así se hace. Estas fuerzas son: el cortante en la base, que es función del peso del edificio, y que se distribuye en todas las plantas en función de su altura, se aplica con una excentricidad 0,05 veces la dimensión del edificio, lo que provoca cierta torsión, además se aplica un incremento de fuerzas verticales debido al sismo que de nuevo son una fracción del peso y de la aceleración.

Los cálculos ofrecen un resultado teórico muy esperanzador (Figura 4), la acción sísmica incrementa las tensiones de manera considerable en las esquinas. Debido a que el prototipo de ladrillo pesa menos que el de adobe (Tabla 1) y a que la acción sísmica es proporcional a esta, los resultados del análisis dan que el prototipo de ladrillo necesita el mismo refuerzo pero con una separación menor. Finalmente se opta por armar ambos prototipos de la misma manera, con los resultados del cálculo para adobe. El dimensionado elegido es el siguiente:

- Armadura del modelo de ensayo $\left(3 \times 3 \times 3 \mathrm{~m}^{3}\right): 2$ alambres longitudinales de $5 \mathrm{~mm}$ a cada lado de una cercha de alambre en zigzag de $5 \mathrm{~mm}$ separados $150 \mathrm{~mm}$. La disposición del armado de paredes y forjados es cada $45 \mathrm{~cm}$, en vertical y horizontal.

- Esto corresponde con una armadura del edificio a escala real $\left(6 \times 6 \times 6 \mathrm{~m}^{3}\right)$ : 2 alambres longitudinales de

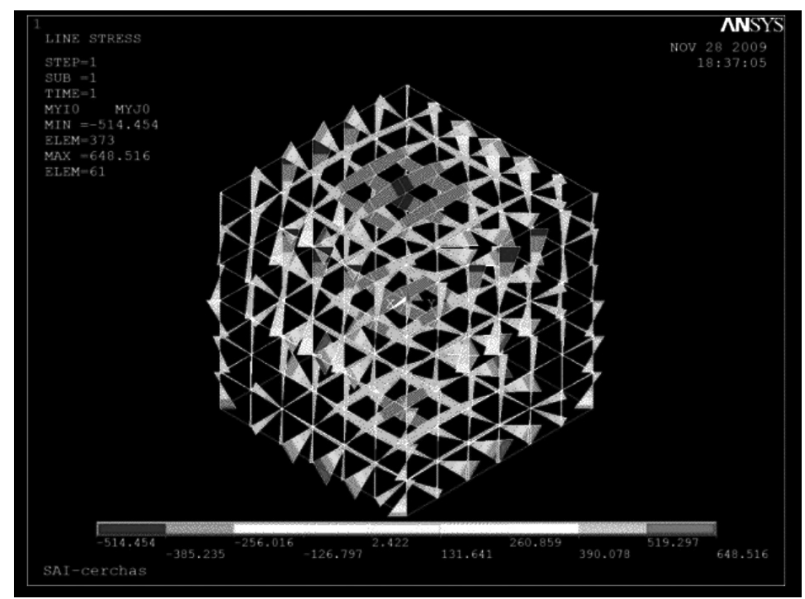

Figura 4. Gráfica de momentos flectores de las barras con el análisis sísmico de la estructura.

Figure 4. Graph of flexural moments of the bars with the structure's seismic analysis. force, since it considers that the elements of horizontal and vertical reinforcement allow the energy dissipation keeping the stability of the structure, this coefficient is 6 for allowable efforts and 3 for strains. Due to the seismic zone (zone 3), the building category (dwelling) and the structural regularity, the regulation allows the use of any structural system. On another hand due to the height of the structure and its regularity, this regulation allows the carrying out of static calculation of equivalent force and it is done so. These forces are: the shearing force at the base, function of the weight of the building, and distributed in all the floors depending on their height, applied with an eccentricity 0.05 times de size of the building, which causes some torsion. An increase of the vertical forces, which are again a fraction of the weight and the acceleration, is also applied due to the earthquake.

The calculations offer a theoretical result very encouraging (Figure 4). The seismic action increases the tensions in the corners in a considerable way. Due to the fact that the brick prototype weighs less than the adobe one (Table 1) and the seismic action is proportional to it, the analysis results show that the brick prototype needs the same reinforcement but with a lesser separation. Finally it is decided to reinforce both prototypes the same way, corresponding to the calculations with adobe. The sizing chosen is the following:

- Bars of the testing model $\left(3 \times 3 \times 3 \mathrm{~m}^{3}\right)$ : two $5 \mathrm{~mm}$ longitudinal wires each side of a $5 \mathrm{~mm}$ zigzag wire truss separated $150 \mathrm{~mm}$. The placement of the reinforcement in walls and floors is every $45 \mathrm{~cm}$, vertically and horizontally.

- This matches a real scale bars of the building $\left(6 \times 6 \times 6 \mathrm{~m}^{3}\right)$ : two $10 \mathrm{~mm}$ longitudinal wires each side

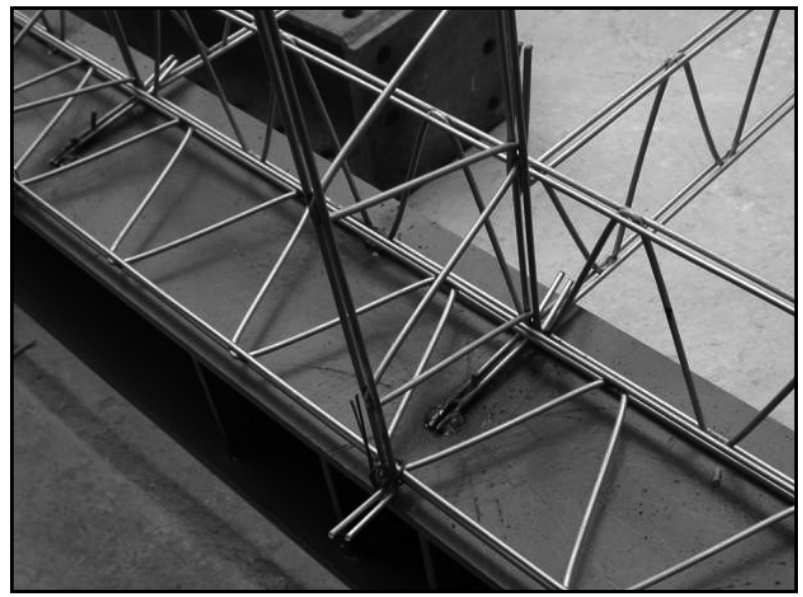

Figura 5. Las cerchas se montan sobre una viga base. Figure 5. These trusses are assembled on a ring, base beam. 
$10 \mathrm{~mm}$ a cada lado de una cercha de alambre en zigzag de 2 alambres de $5 \mathrm{~mm}$, separados $300 \mathrm{~mm}$. La disposición del armado de paredes y forjados con una separación de $90 \mathrm{~cm}$. Módulo que permite abrir puertas y ventanas y paso de escaleras, con dicha organización estructural en un edificio habitable.

Estas cerchas se montan sobre un anillo, viga base, un perfil HEB (Figura 5). Se emplea el mismo refuerzo en los dos ensayos; tras el ensayo con adobe se desmonta el relleno, se limpian los alambres, se sustituyen las cerchas dañadas del forjado de cubierta y se vuelven a construir los muros, esta vez con ladrillo hueco, para el segundo ensayo (Figura 9 derecha).

\subsection{El relleno}

En el primer prototipo los intersticios se rellenan con adobe local y con ladrillo hueco en el segundo. Las piezas de adobe se realizan con una proporción de tierraarena-paja 5:1:1 (Figura 6). El tamaño de las piezas es $15 \mathrm{~cm}$ x $8 \mathrm{~cm}$ de sección y de largo $28 \mathrm{~cm}$ y $14 \mathrm{~cm}$, con estos dos tipos se consiguió aparejar cada uno de los paños.

El muro de adobe tiene $15 \mathrm{~cm}$ de grueso. Dos de los muros se enfoscan (uno frontal y otro lateral a la acción sísmica) al interior y exterior con una malla polimérica (6) cuadrada de $15 \times 15 \mathrm{~mm}$ (Figura 7) unidas por unas tiras de rafia que atraviesan el muro y que las ata (Figura 9 izquierda).

En el prototipo 2 se utilizaron ladrillos de arcilla cocida (Figura 8). La sección transversal del ladrillo fue de $11 \times 9,5 \mathrm{~cm}$ y se necesitó ladrillos de longitudes $24 \mathrm{~cm}$ (enteros), $18 \mathrm{~cm}$ (cortados), y 13,5 cm (cortados y tapados). El espesor del muro es de $11 \mathrm{~cm}$ (menor que el canto de las cerchas) y dos de las fachadas se enfoscan posteriormente con mortero de cemento.

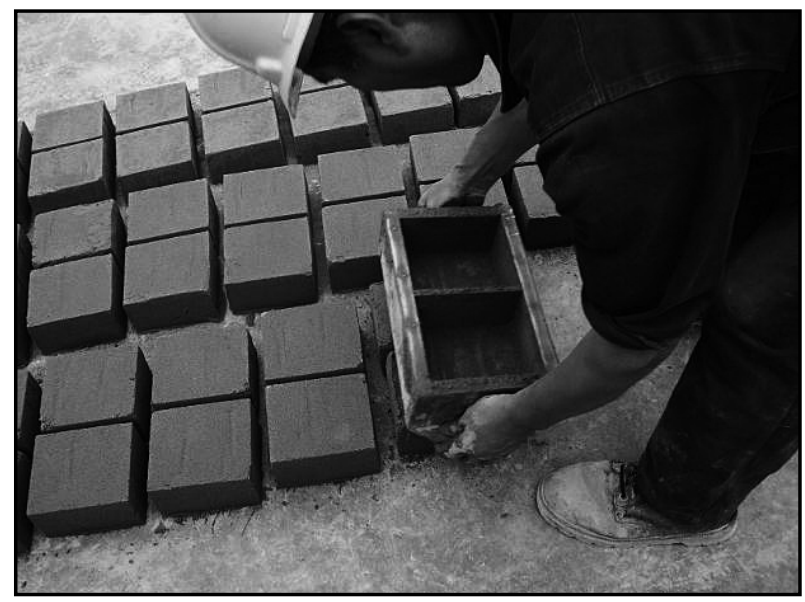

Figura 6. Preparación de las piezas de adobe. Figure 6. Preparation of the adobe pieces. of a two $5 \mathrm{~mm}$ zigzag wires truss, separated $300 \mathrm{~mm}$. The placement of the reinforcement in walls and floors has a separation of $90 \mathrm{~cm}$. Module which allows the opening of doors and windows and stairwell, with the aforementioned structural organization in a livable-in building.

These trusses are assembled on a ring, base beam, $\mathrm{H}$ beam (Figure 5). The same reinforcement is used in both tests; after the test with adobe the filler is dismantled. The wires are cleaned. The damaged trusses in the roofing are replaced and the walls are rebuilt, this time with hollow brick, for the second test (Figure 9 right).

\subsection{The filler}

In the first prototype the gaps are filled with local adobe and hollow brick in the second one. The adobe pieces are made with a 5:1:1 soil-sand-straw ratio. (Figure 6). The size of the pieces is $15 \mathrm{~cm} \times 8 \mathrm{~cm}$ in section and 28 $\mathrm{cm}$ and $14 \mathrm{~cm}$ in length, each panel could be bonded with these two types.

The adobe wall has $15 \mathrm{~cm}$ thick. Two of the walls are rough-casted (one frontal and the other one lateral to the seismic action) to the interior and the exterior with a polymeric mesh (6) with squares of $15 \times 15 \mathrm{~m}$ (Figure 7) attached by raffia strips which go through the wall and ties them (Figure 9 left).

Fired clay bricks were used in prototype 2 (Figure 8). The brick's cross section was of $11 \times 9.5 \mathrm{~cm}$ and bricks with lengths of 24 (whole), $18 \mathrm{~cm}$ (cut), y $13.5 \mathrm{~cm}$ (cut and covered). The wall's thickness is $11 \mathrm{~cm}$ (less than the side of the trusses) and two of the faces are later filled with cement mortar.

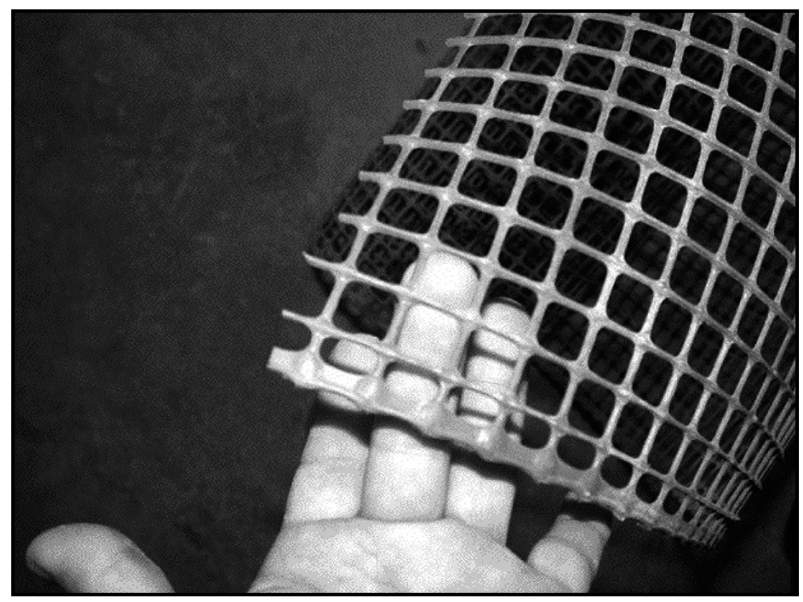

Figura 7. Malla polimérica.

Figure 7. Polymeric mesh. 


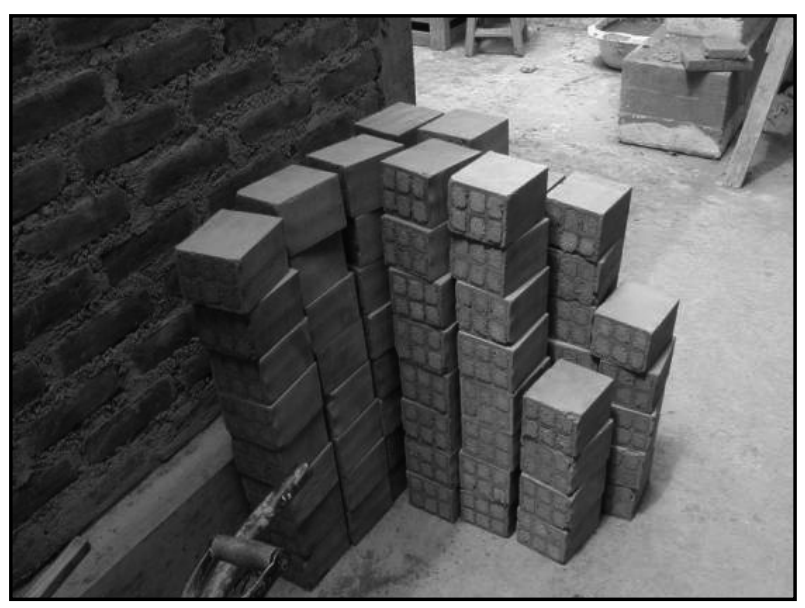

Figura 8. Ladrillo hueco doble.

Figure 8. Double hollow brick.

\subsection{Otras características}

El proceso constructivo es muy sencillo debido a la ligereza de las piezas, y a la prefabricación de las armaduras. Los forjados no se construyen en su totalidad, sólo se dispone la parrilla de armado; el relleno, acabados y sobrecargas se simulan con carga adicional con sacos de arena (Figura 10). El valor de la sobrecarga a aplicar se determina en función del tipo constructivo local, las edificaciones de adobe se realizan con forjados ligeros que no exceden de $1 \mathrm{kN} / \mathrm{m}^{2}$, mientras que en el caso del ladrillo son forjados de unos $3 \mathrm{kN} / \mathrm{m}^{2}$, a esto se añade $1 \mathrm{kN} / \mathrm{m}^{2}$ de peso del pavimento y una carga viva de $2 \mathrm{kN} / \mathrm{m}^{2}$ de la cual se considera que está presente sólo el $25 \%$ durante la ocurrencia del sismo (Tabla 1). Debido a que el prototipo de ladrillo pesa menos se prevé que el efecto de la acción sísmica sea menos desfavorable.

\subsection{Other characteristics}

The building process is very simple due to the lightness of the pieces, and the prefabrication of the bars. The entirety of the floors only has the reinforcement grid. The filler, finishing's and overloads are simulated with the additional load of sand sacks (Figure 10). The value of the overload to apply is determined depending on the local constructive type. The adobe buildings are made with light floors not exceeding $1 \mathrm{kN} / \mathrm{m}^{2}$, whereas in the case of brick the floors are about $3 \mathrm{kN} / \mathrm{m}^{2}$. Added to this are $1 \mathrm{kN} / \mathrm{m}^{2}$ of paving weight and a overload of $2 \mathrm{kN} / \mathrm{m}^{2}$ of which only a $25 \%$ is considered to be present during the earthquake (Table 1). Due to the fact that the brick prototype weighs less it is expected that the effect of the seismic action will be less unfavourable.

Tabla 1 / Table 1

Pesos de los componentes del módulo. Weights of the module's components.

\begin{tabular}{|c|c|c|}
\hline Componente / Component & Peso adobe / Adobe weight (kN) & Peso ladrillo / Brick weight (kN) \\
\hline Base de acero / Steel base & 5.48 & 5.48 \\
\hline Cerchas metálicas / Metallic trusses (98) & 2.21 & 2.21 \\
\hline Muros de adobe o ladrillo / Adobe or brick walls* & 79.17 & 43.57 \\
\hline Enfoscado de barro o cemento / Mud or cement rough-cast* & 7.85 & 5.72 \\
\hline Sobrecarga / Overload & 7.64 & 17.64 \\
\hline Total / Total & 102.35 & 74.62 \\
\hline
\end{tabular}

* Valores estimados / Estimated values.

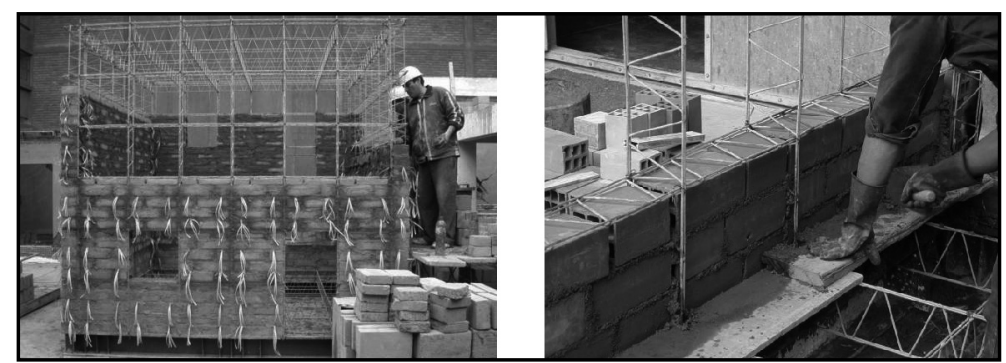

Figura 9. Construcción de los prototipos, a la izquierda de adobe y a la derecha de ladrillo hueco.

Figure 9. Construction of the prototypes, adobe to the left and hollow brick to the right. 


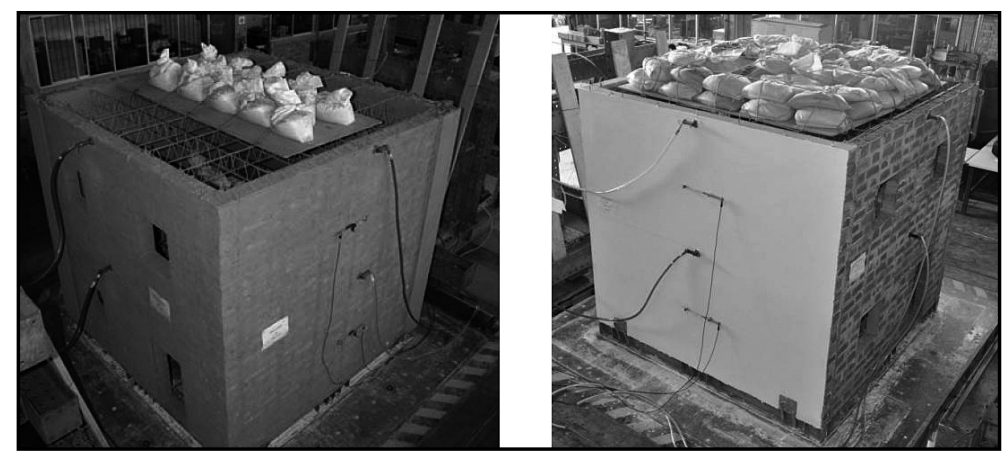

Figura 10. Prototipos de adobe y ladrillo terminados, antes del ensayo.

Figure 10. Finished adobe and brick prototypes, before the testing.

\section{PROGRAMA EXPERIMENTAL}

El ensayo se realiza en la mesa de simulación sísmica del Laboratorio de Estructuras antisísmicas del Departamento de Ingeniería de la Pontificia Universidad Católica del Perú, que es la entidad más representativa dentro del país. La mesa tiene un solo grado de libertad (de los seis de un sismo real), el desplazamiento en un sentido. Los prototipos se disponen de manera que las fachadas con huecos (puerta y ventanas) quedan perpendiculares al sentido del movimiento y las fachadas ciegas en paralelo.

El movimiento (señal de comando) que se aplica a la plataforma del simulador proviene de la componente longitudinal $\left(\mathrm{N} 8^{\circ} \mathrm{O}\right)$ de la aceleración medida en Lima del Terremoto de Ancash del 31 de mayo de 1970. El registro original, obtenido en un acelerógrafo analógico, fue procesado por el United States Geological Survey (USGS) para obtener una aceleración digital corregida, que sirvió de base para generar la señal de comando denominada "mayo70" (el estándar en el citado Laboratorio). Debido a que se ensaya un modelo a escala, se utilizó una versión comprimida en el tiempo de esta señal ("mayo70co") modificando sus frecuencias fundamentales en función de las de la estructura escalada. De esta manera se pasa de 100 puntos por segundo de la señal original a 133,3 puntos por segundo en la señal modificada, de acuerdo al factor de escala físico (1/2) del prototipo. Como consecuencia de esta operación, para un desplazamiento determinado, la señal comprimida ("mayo70co") produce aceleraciones mayores que la señal original.

El ensayo dinámico se realizó en una secuencia de movimientos (fases) de amplitud creciente, con la misma señal de comando. Cada fase se define por el desplazamiento máximo absoluto alcanzado. Inicialmente: se programaron tres primeras fases, en orden creciente de intensidad, correspondientes a un sismo frecuente (leve), uno ocasional (moderado) y uno raro (severo). En el caso de "mayo70co", esos movimientos corresponden a desplazamientos máximos de 20,50 y $80 \mathrm{~mm}$, respectivamente. Las aceleraciones esperadas en la base del

\section{EXPERIMENTAL}

The test is carried out in the earthquake shaking table of the Laboratory of Anti-seismic Structures of the Department of Engineering, Pontifical Catholic University of Peru. It is the most representative entity in the country. The table has only one degree of freedom (out of the six of a real earthquake), the movement in one direction. The prototypes are placed so that the faces with gaps (door and windows) are perpendicular to the direction of the movement and the blind faces are parallel to it.

The movement (command signal) applied to the platform of the simulator comes from the longitudinal component $\left(\mathrm{N} 8^{\circ} \mathrm{O}\right)$ of the acceleration measured in Lima at the Earthquake of Ancash in May 31 1970. The original record, obtained with an analog accelerograph, was processed by the United States Geological Survey (USGS) to obtain a corrected digital acceleration, which was the base to generate the command signal named "mayo70" (the standard in said Laboratory). Because what was being tested was a scale model, a version of this signal compressed in time ("mayo70co") was used, modifying its fundamental frequencies depending on the escalated structure. This way the 100 points per second of the original signal go up to the 133.3 points per second of the modified signal, according to the physical scale factor (1/2) of the prototype. As a result of this operation, for a determined movement, the compressed signal ("mayo70co") creates higher accelerations than the original signal.

The dynamic test was carried out in a sequence of movements (phases) of increasing range, with the same command signal. Each phase is defined by the absolute maximum movement reached. Initially, three first phases were scheduled, in ascending order of intensity, corresponding to a frequent earthquake (mild), and occasional one (moderated) and a rare one (severe). In the case of "mayo70co", those movements correspond to maximum displacements of 20, 50 and $80 \mathrm{~mm}$, respectively. The accelerations expected at the base of 
módulo para esos desplazamientos son $0,3 \mathrm{~g}, 0,7 \mathrm{~g}$ y $1,1 \mathrm{~g}$, aproximadamente.

Finalmente se somete el conjunto a una cuarta fase con la señal del comando original "mayo70" con una amplitud máxima de $130 \mathrm{~mm}$ (capacidad máxima del simulador) con una aceleración estimada en la base de 1,8 g. En los muros se colocan los instrumentos de medición de la aceleración producida y desplazamientos, Figura 11. the module for these movements are $0.3 \mathrm{~g}, 0.7 \mathrm{~g}$ and $1.1 \mathrm{~g}$, approximately.

Finally the whole is subjected to a fourth phase with the original command signal "mayo70" with a maximum range of $130 \mathrm{~mm}$ (maximum capacity of the simulator) with an estimated acceleration at the base of $1.8 \mathrm{~g}$. The measurements tools for the acceleration and movements are place in the walls, Figure 11.

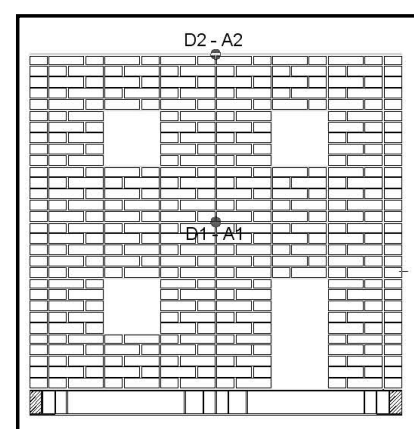

Elevación muro MA

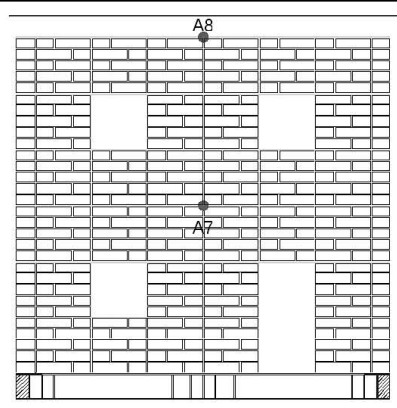

Elevación muro MP

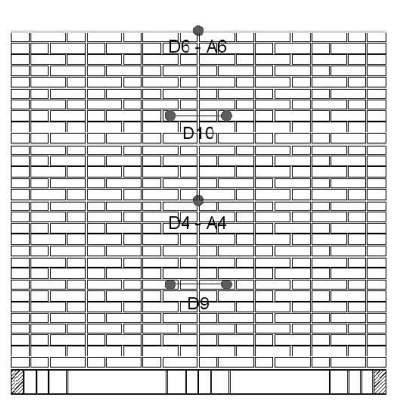

Elevación muro Ml

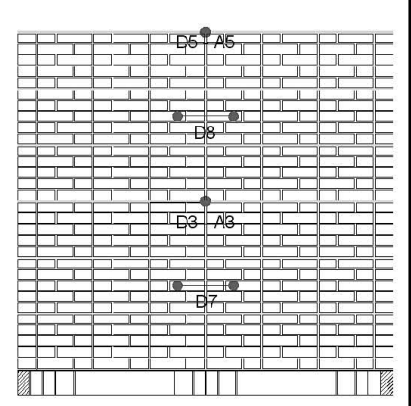

Elevación muro MD

Figura 11. Ubicación de instrumentos de medición en muros. Fachadas MA y MD están enfoscadas. Figure 11. Placement of measurement tools in walls. The faces MA and MD are rough casted.

Tabla 2 / Table 2

Valores máximos de los instrumentos de medición (D0-D10 miden desplazamientos relativos). Prototipos 1 y 2. Maximum values of the measurement tools (D0-D10 measure relative displacements). Prototypes 1 and 2.

\begin{tabular}{|c|c|c|c|c|c|c|c|c|}
\hline & \multicolumn{2}{|c|}{ Fase 1 / Phase 1} & \multicolumn{2}{|c|}{ Fase 2 I Phase 2} & \multicolumn{2}{|c|}{ Fase 3 / Phase 3} & \multicolumn{2}{|c|}{ Fase 4 / Phase 4} \\
\hline & Adobe & Ladrillo / Brick & Adobe & Ladrillo / Brick & Adobe & Ladrillo / Brick & Adobe & Ladrillo / Brick \\
\hline D0 (mm) & 20.56 & 19.79 & 50.46 & 49.01 & 82.29 & 79.51 & 129.56 & 130.45 \\
\hline $\mathrm{D} 1(\mathrm{~mm})$ & 20.67 & 20.00 & 59.72 & 499.78 & 93.25 & 80.80 & 158.88 & 129.11 \\
\hline $\mathrm{D} 2(\mathrm{~mm})$ & 22.66 & 20.43 & 65.35 & 49.53 & 138.89 & 82.12 & 189.83 & 136.31 \\
\hline $\mathrm{D} 3(\mathrm{~mm})$ & 20.49 & 20.29 & 54.05 & 50.41 & 96.65 & 81.95 & 147.94 & 131.28 \\
\hline $\mathrm{D} 4(\mathrm{~mm})$ & 21.12 & 19.53 & 62.13 & 49.54 & 114.52 & 79.59 & 164.88 & 128.53 \\
\hline $\mathrm{D} 5(\mathrm{~mm})$ & 20.72 & 20.40 & 54.46 & 50.71 & 102.31 & 82.69 & 156.30 & 132.47 \\
\hline $\mathrm{D} 6(\mathrm{~mm})$ & 26.43 & 20.28 & 70.72 & 49.31 & 142.51 & 79.69 & 189.49 & 126.71 \\
\hline D7 (mm) & 0.072 & 0.027 & 0.067 & 0.034 & 0.25 & 0.031 & 0.358 & 0.030 \\
\hline D8 (mm) & 0.094 & 0.059 & 0.081 & 0.238 & 3.761 & 0.201 & 0.734 & 0.075 \\
\hline $\mathrm{D} 9(\mathrm{~mm})$ & 0.352 & 0.032 & 0.406 & 0.038 & 0.536 & 0.056 & 4.079 & 0.103 \\
\hline $\mathrm{D} 10(\mathrm{~mm})$ & 0.122 & 0.045 & 0.348 & 0.047 & 0.315 & 0.046 & 0.437 & 0.047 \\
\hline
\end{tabular}

Tabla 3 / Table 3

Valores máximos de los instrumentos de medición (A0-A8 miden aceleraciones), Prototipos 1 y 2. Maximum values of the measurement tools (A0-A8 measure accelerations), Prototypes 1 and 2.

\begin{tabular}{|c|c|c|c|c|c|c|c|c|}
\hline & \multicolumn{2}{|c|}{ Fase 1 / Phase 1} & \multicolumn{2}{|c|}{ Fase 2 / Phase 2} & \multicolumn{2}{|c|}{ Fase 3 / Phase 3} & \multicolumn{2}{|c|}{ Fase 4 / Phase 4} \\
\hline & Adobe & Ladrillo / Brick & Adobe & Ladrillo / Brick & Adobe & Ladrillo / Brick & Adobe & Ladrillo / Brick \\
\hline $\mathrm{A0}(\mathrm{g})$ & 0.281 & 0.310 & 0.733 & 0.803 & 1.173 & 1.309 & 1.181 & 1.486 \\
\hline A1 (g) & 0.581 & 0.331 & 0.962 & 0.980 & 1.258 & 1.729 & 1.399 & 1.815 \\
\hline A2 (g) & 1.1126 & 0.377 & 1.779 & 1.172 & 3.155 & 2.227 & 2.737 & 2.229 \\
\hline A3 (g) & 0.501 & 0.348 & 1.295 & 0.890 & 2.213 & 1.404 & 2.168 & 1.486 \\
\hline A4 (g) & 0.746 & 0.338 & 1.091 & 0.893 & 1.752 & 1.392 & 1.917 & 1.534 \\
\hline A5 (g) & 0.509 & 0.342 & 1.501 & 0.920 & 3.062 & 1.551 & 3.370 & 1.640 \\
\hline A6 (g) & 1.638 & 0.344 & 3.212 & 0.915 & 3.330 & 1.452 & 2.787 & 1.607 \\
\hline A7 (g) & 0.727 & 0.351 & 1.097 & 1.012 & 1.396 & 1.789 & 1.484 & 1.904 \\
\hline A8 (g) & 1.300 & 0.354 & 2.075 & 1.102 & 3.195 & 2.156 & 2.940 & 2.131 \\
\hline
\end{tabular}




\section{RESULTADOS Y ANÁLISIS}

Los ensayos muestran un comportamiento sismorresistente (7 y 8 ) de ambos prototipos. El prototipo de adobe se agrieta significativamente sin perder la estabilidad (Figura 12). Las grietas se producen marcando las armaduras, más gruesas cerca de la base, como cabía esperar. Los muros perpendiculares a la acción sísmica son los que menos se agrietan. En el prototipo de ladrillo se observan pequeñas fisuras de las piezas de ladrillo (Figura 14) y deformaciones del entramado de los forjados y apenas se perciben fisuras generales (Figura 13). Sin embargo los instrumentos de medición indican que los movimientos producidos son del orden de $0,1 \mathrm{~mm}$.

\section{RESULTS AND ANALYSIS}

The tests show an earthquake resistant performance/ behaviour (7 and 8) from both prototypes. The adobe prototype cracks significantly without losing stability (Figure 12). The cracks occur marking the bars, thicker close to the base, as expected. The walls perpendicular to the seismic action are the ones which crack the less. In the brick prototype small fissures in the brick pieces (Figure 14) and deformations of the floors' framework can be observed and there's barely noticeable general fissures (Figure 13). However the measurement tools indicate that the movements are of the order of $0.1 \mathrm{~mm}$.

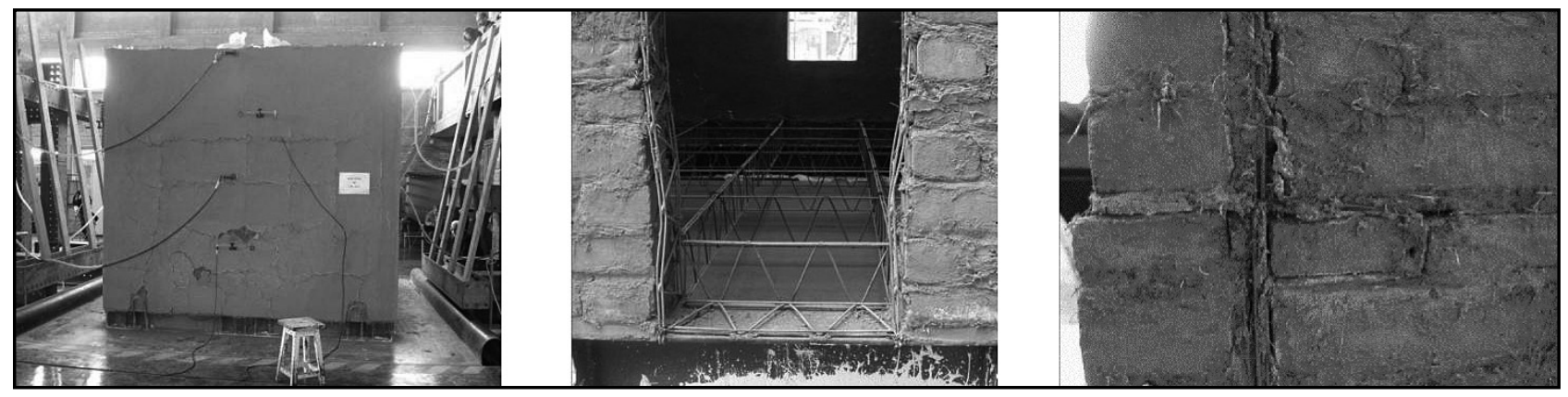

Figura 12. Aspecto del prototipo de adobe después del ensayo. Vista general, puerta y una esquina. Figure 12. Look of the adobe prototype after the test. General view, door and a corner.

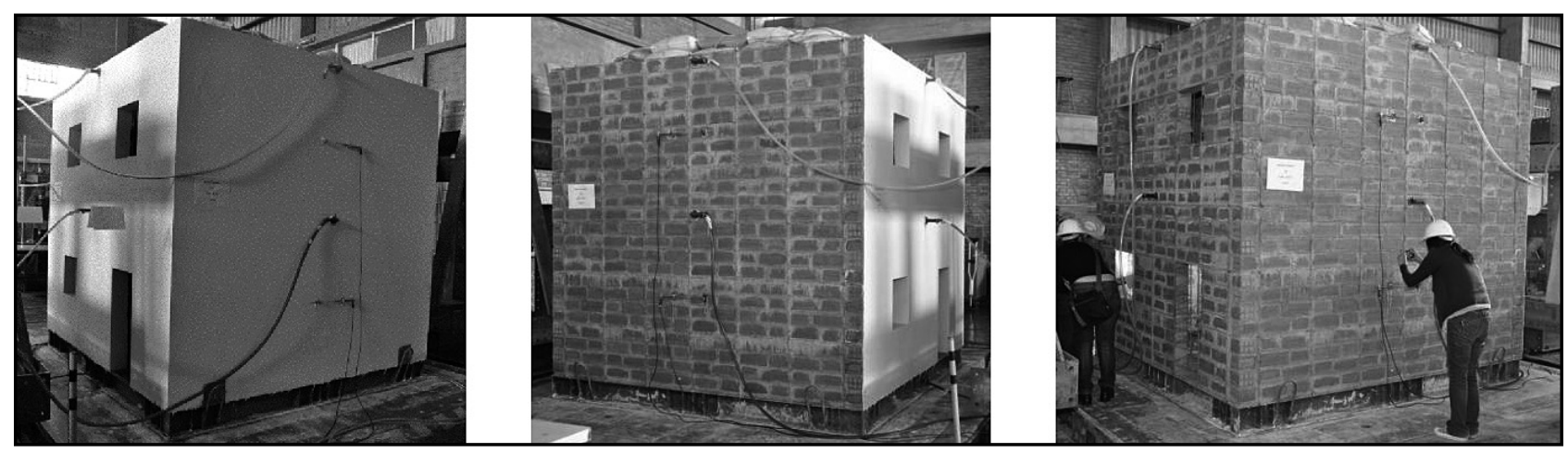

Figura 13. Aspecto del prototipo de ladrillo después del ensayo sin apenas fisuras. Figure 13. Look of the brick prototype after the test with barely any fissures.

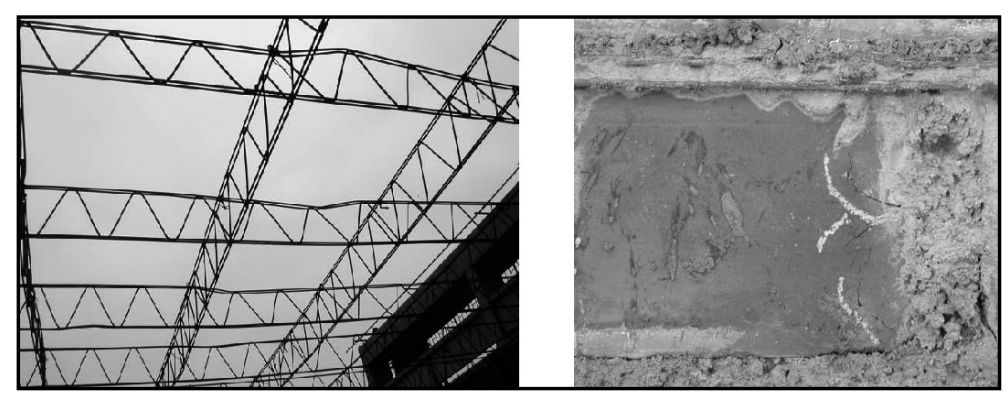

Figura 14. Prototipo de ladrillo: las cerchas de los forjados sufren deformaciones considerables y pequeñas fisuras de algunas piezas. Figure 14. Brick prototype: the trusses of the slab sustain considerable deformations and small fissures in some of the pieces. 
En ambos casos se observa que el armado en dos direcciones de muros y forjado permite la disipación de la energía manteniendo la estabilidad de la estructura, por lo que la hipótesis de cálculo planteada es correcta.

Los valores máximos de los instrumentos de medición se indican en la Tabla 2. Los desplazamientos relativos D7 a D10 marcan la apertura máxima de las grietas medidas durante el ensayo, siendo el valor máximo de 4,1 $\mathrm{mm}$ en la fase 4 en adobe y $0,1 \mathrm{~mm}$ en la misma fase en el prototipo de ladrillo. Los desplazamientos máximos medidos en la coronación del modelo son ligeramente superiores a los aplicados en la base.

Las aceleraciones medidas en puntos alejados de la base muestran valores de hasta el doble de la aceleración en la base en el prototipo de adobe, debido a su mayor peso total; en el prototipo de ladrillo, sin embargo, son del mismo orden de magnitud (Tabla 3).

En ambos casos el relleno colabora en la resistencia del sismo, permanece confinado en los espacios entre cerchas impidiendo su pandeo. Los forjados no están colaborando como se esperaba debido a que no se han ejecutado en su totalidad y por lo tanto carecen de resistencia a compresión. Las esquinas también se muestran como una zona débil (Figura 12 derecha).

\section{CONCLUSIONES}

Los resultados de los ensayos muestran que el SAI con adobe o ladrillo tiene un comportamiento sismorresistente frente a la solicitación dinámica del simulador, la estructura permanece estable por lo que se logra el objetivo buscado. En general, el sistema tiene un comportamiento altamente dúctil gracias al armado dispuesto. El prototipo de adobe se agrieta significativamente. El estado final es tal que, reparando las grietas provocadas, se puede prolongar su vida útil y soportar sismos futuros. El prototipo de ladrillo tiene un comportamiento mucho mejor, sin apenas fisuras. Por lo tanto es un sistema parece idóneo para la construcción de viviendas en zonas sísmicas.

El sistema constructivo ha resultado de fácil puesta en práctica, a pesar de ser la primera utilización del sistema en el país; los operarios asimilaron sin mayor dificultad el procedimiento.

El enfoscado de los muros no influye significativamente en su comportamiento en ninguno de los prototipos.

Para validar con seguridad el sistema constructivo es necesario probar un modelo a escala real. Está previsto realizar este ensayo con relleno de ladrillo hueco debido
In both cases it is observed that the framework in two directions of walls and floor allows the energy dissipation keeping the structure's stability, hence the calculation hypothesis proposed is correct.

Los maximum values from the measurement tools are indicated in Table 2. The relative displacements $D 7$ to D10 mark the maximum opening of the cracks measured during the test, $4.1 \mathrm{~mm}$. The maximum in phase 4 for adobe and $0.1 \mathrm{~mm}$ in the same phase for the brick prototype. The maximum displacements measured in the model's crowning point are slightly higher to those applied at the base.

The accelerations measured in points away from the base show values up to twice the acceleration at the base in the adobe prototype, due to its higher overall weight. In the brick prototype however they are of the same order of magnitude (Table 3).

In both cases the filler contributes to the earthquake resistance. It stays confined to the spaces between trusses preventing their buckling. The floors are not collaborating as expected because they have not been built completely and therefore lack in compression strength. The corners also appear as a weak zone (Figure 12 right).

\section{CONCLUSIONS}

The results of the tests show that the IMS with adobe or brick has an earthquake resistant performance opposite to the dynamic stressing of the simulator, the structure remains stable and therefore the objective sought is reached. In general the system has a performance highly ductile thanks to the disposed reinforcement. The adobe prototype cracks significantly. The final state is such that, repairing the cracks sustained, its useable life can be extended and endure future earthquakes. The brick prototype has a much better performance, with barely any fissure. It seems therefore an ideal system for the construction of dwellings in seismic areas.

The constructive system was easily put into practice, in spite of it being the first use of the system in the country. The operators assimilated with no difficulty the procedure.

The rough-cast of the walls does not have a significant influence on its performance in any of the prototypes.

To validate securely the constructive system it is necessary to test a model at real scale. It is planned to carry out this test with hollow brick filler because it has 
a que ha demostrado un mejor comportamiento. Debido a las características de la mesa sísmica sería necesario además probar el modelo con una arquitectura más crítica, es decir, con los vanos colocados en los muros paralelos a la dirección del movimiento.

Estos ensayos abren una vía de aplicación de este sistema como una solución al problema de la construcción sísmica con fábrica, pudiendo ser con ladrillo, adobe u otro material y particularmente considerando los últimos sismos en Perú, Haití y Chile.

\section{AGRADECIMIENTOS}

Deseamos agradecer a Marcial Blondet, Gladis Villa García y Francisco Ginocchio su participación en el proyecto. Al personal del Laboratorio su colaboración en la construcción de los prototipos a los estudiantes de postgrado de la PUCP que han colaborado en el ensayo y su monitorización, Yalí Barrera Candela, Elisa Quintanilla, José Pérez Costa, Fidel Loyola y Julio César Chang. Incluir también a los becarios de la UPM Alberto Humanes Cisnal y Pablo Gris Martínez por su labor de apoyo en el cálculo y dimensionado de los prototipos. shown a better performance. Due to the characteristics of the earthquake shaking table it would also be necessary to test the model with a more critical architecture, that is, with the openings placed in the walls parallel to the direction of the movement.

These tests open an application route of this system as a solution to the problem of seismic construction with masonry, be it with brick, adobe or another material and particularly considering the last earthquakes in Peru, Haiti and Chile.

\section{ACKNOWLEDGEMENTS}

We wish to thank Marcial Blondet, Gladis Villa García y Francisco Ginocchio for their participation in the project. We want to be grateful to the personnel of the Laboratory for their collaboration in the construction of the prototypes, to the postgraduate students of the PUCP who have collaborated in the test and its monitorization, Yalí Barrera Candela, Elisa Quintanilla, José Pérez Costa, Fidel Loyola and Julio César Chang. Including also the UPM interns Alberto Humanes Cisnal and Pablo Gris Martínez for their support work in the design and sizing of the prototypes.

\section{BIBLIOGRAFÍA / BIBLIOGRAPHY}

(1) Adell, J. M.; Bustamante, R.; Dávila, D.: "La vivienda de adobe sismorresistente con el Sistema de Albañilería Integral", Seminario Internacional SismoAdobe, Lima Perú, 2005.

(2) Orta Rial, B. et al.: "Ensayo en Lima (Perú) de edificio de adobe sismorresistente construido con el sistema de albañilería integral". Informes de la Construcción, vol. 61, no 515 (2009), pp. 59-65. doi: 10.3989/ic.09.006

(3) Orta-Rial, B.: "Trusses optimisation under multiple variable load", Proceedings of the 8th International Conference on Computing in Civil and Building Engineering, California, USA. August 2000. http://dx.doi.org/10.1061/40513(279)189

(4) Adell, J. M.; Lauret, B.: "El sistema de albañilería integral AllWall con BHH/BLOC+". Informes de la Construcción, vol. 57, no 495 (2005), pp. 33-43.

(5) NTE E.030 Diseño Sismorresistente, Ministerio de Vivienda, Construcción y Saneamiento. Lima 2003.

(6) Blondet, M.; Torrealva, D.; Villa García, G.; Ginocchio, F.; Madueño, I.: Reforzamiento de construcciones de adobe con elementos producidos industrialmente: Estudio preliminar. PUCP. Lima, Perú, 2004.

(7) Adobe sismorresistente fase 4 del ensayo del prototipo 1/2 en 2008. http://www.youtube.com/watch?v=xZ5QtM3PNNc

(8) Construcción sismorresistente de Ladrillo. Fase 4 del ensayo del prototipo 1/2 en 2009. http://www.youtube.com/ watch?v=kyhBoRdAt54 